\title{
Analisis Pengaruh Kepemilikan Manajerial terhadap Kebijakan Pendanaan dan Dividen
}

\author{
Nofrida Utami Gustian \\ Departemen Manajemen, Fakultas Ekonomi dan Manajemen \\ Institut Pertanian Bogor \\ Kampus Darmaga Bogor 16680 \\ Ali Mutasowifin \\ Departemen Manajemen, Fakultas Ekonomi dan Manajemen \\ Institut Pertanian Bogor \\ Kampus Darmaga Bogor 16680 \\ e-mail: alimu@ipb.ac.id
}

\begin{abstract}
Banking regulations required banks to manage their capital structure well, including those related to managerial ownership, funding and dividend policies. The primary objective of this research is to analyze the influence of managerial ownership on policies of funding and dividend. By using data of 22 banking companies listed at JSX for the period 2008-2012, we find that managerial ownership is not significantly influence funding policy. On the other hand, it negatively and significantly influences dividend policy.

Keywords : banking, dividend policy, funding policy, managerial ownership
\end{abstract}

\begin{abstract}
ABSTRAK
Regulasi perbankan menuntut bank untuk mengelola struktur permodalan dengan baik, terutama yang berkaitan dengan kepemilikan manajerial, serta kebijakan pendanaan dan dividen. Tujuan utama penelitian ini adalah untuk menganalisis pengaruh kepemilikan manajerial terhadap kebijakan pendanaan dan dividen. Dengan menggunakan sampel 22 bank yang terdaftar pada BEI untuk periode 2008-2012, ditemukan bahwa kepemilikan manajerial tidak signifikan mempengaruhi kebijakan pendanaan, sementara pada kebijakan dividen pengaruhnya negatif dan signifikan.

Kata Kunci : bank, kebijakan dividen, kebijakan pendanaan, kepemilikan manajerial

\section{Pendahuluan}

Terdapat beberapa alasan investor asing tertarik berinvestasi di sektor perbankan di Indonesia. Pertama, perbankan Indonesia cukup aman (prudent) dan dikelola dengan sangat baik. Meskipun aturan Basel III segera diberlakukan, tingkat kecukupan likuiditas bank-bank nasional yang rata-rata sebesar $18 \%$ tidak akan mengalami masalah berarti. Kedua, tingkat keuntungan perbankan di Indonesia sangat menjanjikan, didukung dengan peningkatan laba bersih bank asing maupun umum sejak 2011. Ketiga, prospek ekspansi perbankan di Indonesia masih sangat luas, ditunjukkan oleh rasio aset lembaga perbankan (deposit-taking institution) terhadap produk domestik bruto (PDB) di Indonesia yang baru sekitar $48 \%$ sedangkan Malaysia yang sudah mencapai $180 \%$, Filipina $78 \%$, dan Thailand $137 \%$.
\end{abstract}


Pengelolaan perusahaan bertujuan untuk menyejahterakan pemiliknya melalui pelaksanaan fungsi manajemen keuangan dengan tepat, karena keputusan keuangan dapat berdampak pada nilai perusahaan. Untuk mencapai tujuannya, para pemegang saham mempercayakan pengelolaan perusahaan kepada para profesional untuk meningkatkan nilai kepentingan pemegang saham. Penunjukan manajer oleh pemegang saham seringkali menghadapi masalah perbedaan tujuan perusahaan dengan tujuan pribadi manajer. Berdasarkan kewenangan yang dimiliki, manajer dapat bertindak untuk keuntungan dirinya sendiri dan mengorbankan kepentingan para pemegang saham. Hal ini terjadi karena perbedaan informasi yang dimiliki oleh kedua pihak atau asymmetric information. Asymmetric information ini kemudian dapat menimbulkan agency problem (Putri dan Nasir 2006). Pada perusahaan modern, agency problem, yakni konflik kepentingan antara pemegang saham dan manajemen, senantiasa dianggap sebagai kelemahan yang potensial (Sharma dan Wadhwa 2013).

Beragam penelitian terdahulu terkait kepemilikan manajerial (MOWN) menunjukkan hasil yang beragam. Larasati (2011) menyimpulkan variabel kepemilikan manajerial mempunyai pengaruh yang tidak signifikan terhadap kebijakan utang pada industri manufaktur. Sementara Soesetio (2008), menyatakan kepemilikan manajerial berpengaruh negatif dan signifikan pada sektor industri manufaktur. Berlainan dengan Rachmad dan Muid (2013) yang menunjukkan bahwa pada perusahaan non-keuangan, kepemilikan saham manajerial berpengaruh positif dan signifikan terhadap kebijakan dividen. Sementara Kahar (2008) menyimpulkan kepemilikan manajerial berpengaruh secara positif terhadap kebijakan pendanaan, dan berpengaruh secara negatif terhadap kebijakan dividen. Penelitian ini memberikan kontribusi dengan membahas hubungan antara kepemilikan manajerial terhadap kebijakan pendanaan dan dividen pada sub sektor perbankan.

Struktur modal yang diterapkan setiap perusahaan berbeda-beda, menyesuaikan kebutuhan operasional perusahaan. Berdasarkan karakteristik perbankan yang diatur dengan regulasi dan prinsip kehati-hatian, penelitian ini ingin mengetahui struktur modal yang diterapkan untuk mengambil keputusan pendanaan dan pembagian dividen bagi bank dilihat dari sudut pandang manajemen internal perusahaan.

Gambar 1 menunjukkan jumlah kepemilikan manajerial pada sub-sektor perbankan. Salah satu aspek pengelolaan perbankan ditunjukkan melalui kepemilikan manajerial yang dapat mempengaruhi kesinambungan oprasional perusahaan. Perkembangan pada sub-sektor perbankan selama 5 tahun menunjukkan grafik kepemilikan manajerial yang cukup stabil dan cenderung naik dapat mempengaruhi pengambilan keputusan pendanaan dan pembagian dividen.

Penelitian ini dilakukan untuk mengamati dan menganalisis pengaruh kepemilikan manajerial terhadap kebijakan pendanaan dan dividen. Tujuan penelitian ini adalah : 1) Menganalisis pengaruh kepemilikan manajerial terhadap kebijakan pendanaan; dan 2) Menganalisis pengaruh kepemilikan manajerial terhadap kebijakan dividen. Perumusan masalah untuk penelitian ini adalah 1) apakah kepemilikan manajerial berpengaruh terhadap kebijakan pendanaan?; dan 2) apakah kepemilikan manajerial berpengaruh terhadap kebijakan dividen? 


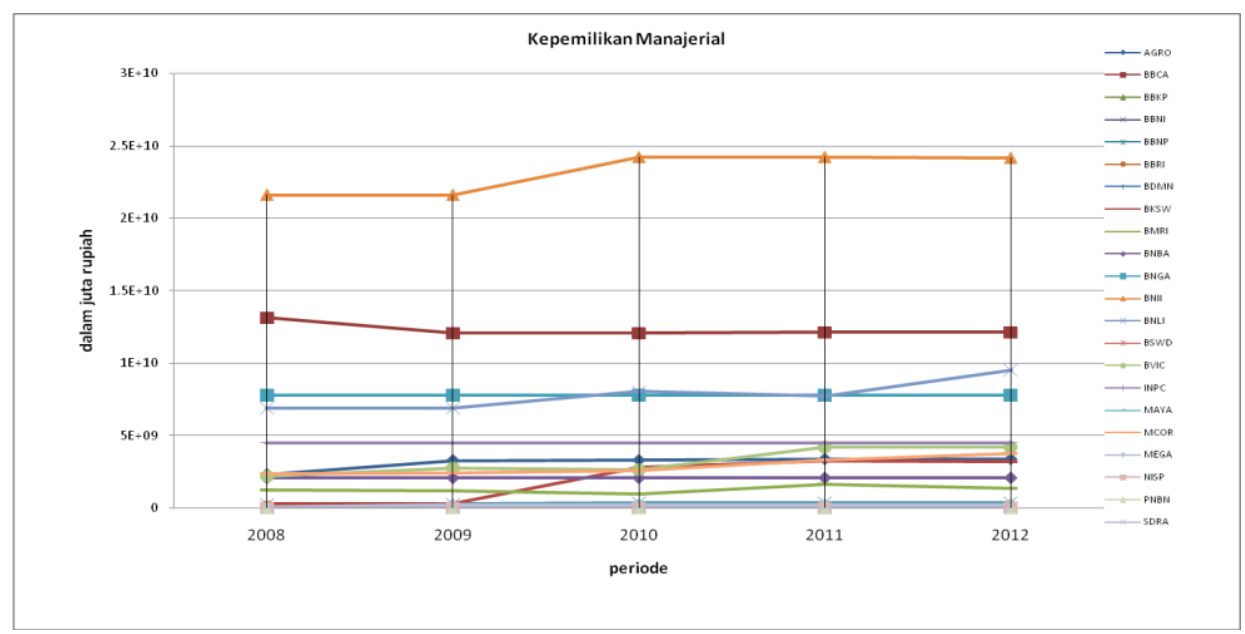

Gambar 1. Grafik kepemilikan manajerial sub sektor perbankan

\section{Metode Penelitian}

Penelitian ini menggunakan tolok ukur dividend payout ratio (DPR) untuk mentukan kebijakan dividen dan kebijakan pendanaan dengan debt equity ratio (DER) terhadap keputusan persentase kepemilikan manajerial perusahaan. Dengan menggunakan analisis regresi, akan dilihat hubungan kepemilikan manajerial terhadap kebijakan dividen, serta kepemilikan manajerial terhadap kebijakan pendanaan.

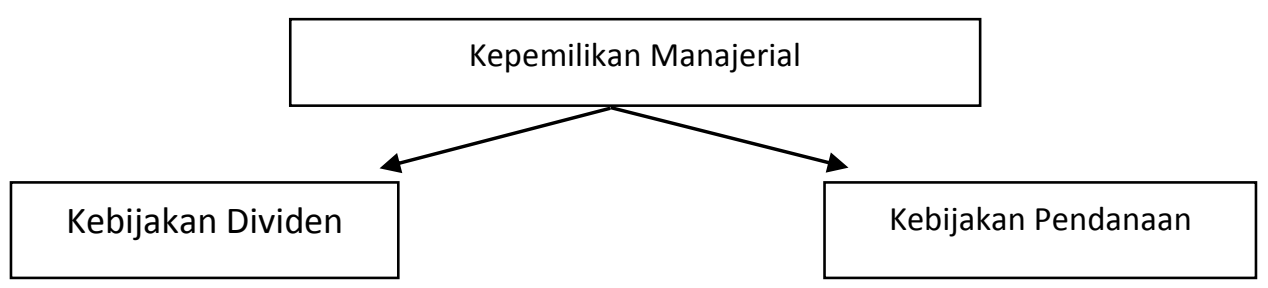

Gambar 2. Model kerangka pemikiran

Terdapat tiga variabel yang digunakan. Pertama, rasio keuangan yang berkaitan dengan struktur modal perusahaan, DER, untuk menghitung dana yang diperlukan perusahaan berdasarkan ekuitas yang dimiliki. Kedua, DPR, perbandingan besarnya dividen yang dibagikan terhadap laba yang diperoleh perusahaan. Ketiga, MOWN, yang diukur dengan menjumlahkan total saham yang dimiliki manajer atau institusi terhadap total saham yang diterbitkan perusahaan (Sharma dan Wadhwa 2013; Malik, et al. 2013).

Perhitungan rasio tersebut mengacu pada laporan keuangan tahunan emiten perbankan di Indonesia. Pengaruh kepemilikan manajerial terhadap kebijakan pendanaan dan dividen dapat dilihat menggunakan analisis regresi. Penelitian dilakukan pada emiten perbankan yang ada di Indonesia, yakni yang tercatat (listed) di Bursa Efek Indonesia (BEI). Data diperoleh dari website perusahaan dan perpustakaan $\mathrm{BEI}$, berupa laporan keuangan tahunan dan laporan dividen yang dipublikasikan pada periode 2008-2012. 
Tabel 1. Daftar perusahaan sampel perbankan di BEI

\begin{tabular}{lll}
\hline No & \multicolumn{1}{c}{ KodeEmiten } & \multicolumn{1}{c}{ Nama Perusahaan } \\
\hline 1. & AGRO & Bank AgroniagaTbk. \\
2. & BBCA & Bank Central Asia Tbk. \\
3. & BBKP & Bank BukopinTbk. \\
4. & BBNI & Bank Negara Indonesia (Persero) Tbk. \\
5. & BBNP & Bank Nusantara ParahyanganTbk. \\
6. & BBRI & Bank Rakyat Indonesia (Persero) Tbk. \\
7. & BDMN & Bank Danamon Indonesia Tbk. \\
8. & BNLI & Bank PermataTbk. \\
9. & BKSW & Bank QNB KesawanTbk. \\
10. & BMRI & Bank Mandiri (Persero) Tbk. \\
11. & BNBA & Bank Bumi ArthaTbk. \\
12. & BNGA & Bank CIMB NiagaTbk. \\
13. & BNII & Bank Internasional Indonesia Tbk. \\
14. & BSWD & Bank of India Indonesia Tbk. \\
15. & BVIC & Bank Victoria InternasionalTbk. \\
16. & INPC & Bank Artha Graha InternasionalTbk. \\
17. & MAYA & Bank Mayapada Tbk. \\
18. & MCOR & Bank Windu Kentjana Internasional Tbk. \\
19. & MEGA & Bank Mega Tbk. \\
20. & NISP & Bank OCBC NISP Tbk. \\
21. & PNBN & Bank Pan Indonesia Tbk. \\
22. & SDRA & Bank Himpunan Saudara 1906 Tbk. \\
\hline & &
\end{tabular}

Larasati (2011) menemukan bahwa pada sektor industri manufaktur, kepemilikan manajerial mempunyai pengaruh tidak signifikan terhadap kebijakan utang perusahaan. Hubungan tidak signifikan ini menggambarkan bahwa manajer perusahaan bukan faktor utama dalam pengambilan keputusan pendanaan dari utang, karena saham manajerial yang dimiliki terlalu kecil. Berlainan dengan Soesetio (2008) yang menyatakan bahwa kepemilikan manajerial berpengaruh negatif dan signifikan pada sektor manufaktur. Hal ini mencerminkan bahwa kepemilikan manajerial mengendalikan biaya keagenan dalam menggunakan utangnya, serta kepemilikan manajerial yang meningkat akan mengurangi risiko kehilangan modal perusahaan. Berdasarkan pertimbangan tersebut, hipotesis pertama pada penelitian ini adalah : $\mathrm{H}_{1}$ : Semakin tinggi kepemilikan manajerial, semakin tinggi DER.

Menurut Kahar (2008), pada sektor industri manufaktur, kepemilikan manajerial berpengaruh positif dan signifikan terhadap DER, serta berpengaruh negatif dan tidak signifikan terhadap DPR. Hal ini terjadi karena kontrol manajerial yang besar membuat perusahaan mampu melakukan investasi lebih baik, sehingga memerlukan tambahan dana melalui utang untuk pendanaannya. Selain itu, manajemen perusahaan cenderung memilih kompensasi berupa gaji, bonus, dan insentif jangka panjang lainnya (remunerasi) dibandingkan pembagian dividen. Kesimpulan berlainan dikemukakan Rachmad dan Muid (2013) yang menunjukkan kepemilikan saham manajerial pada perusahaan non-keuangan berpengaruh positif dan signifikan terhadap kebijakan dividen. Hal ini menggambarkan bahwa manajemen perusahaan memperhatikan besarnya kepemilikan saham yang dimiliki institusi dalam kebijakan dividen. Dengan demikian, hipotesis kedua penelitian ini adalah :

$\mathrm{H}_{2}$ : Semakin tinggi kepemilikan manajerial, semakin rendah DPR. 


\section{Hasil dan Pembahasan}

III.1. Gambaran Industri Perbankan di Indonesia Secara Umum

Terdapat 120 bank di Indonesia yang merupakan bank umum yang terdiri dari bank pemerintah (4) dan bank swasta (116). Perbankan Indonesia berperan penting sebagai penghimpun dan penyalur dana masyarakat serta menunjang pelaksanaan pembangunan nasional dalam rangka meningkatkan pemerataan pembangunan dan hasil-hasilnya, pertumbuhan ekonomi dan stabilitas nasional, ke arah peningkatan taraf hidup rakyat.

Hingga akhir 2013 terdapat 36 bank yang tercatat (listed) di Bursa Efek Indonesia. Terdapat 14 bank yang tidak memenuhi persyaratan penelitian, 10 bank karena baru terdaftar di Bursa Efek Indonesia pada tahun 2008, dan 4 bank lagi, yaitu Bank ICB Bumiputera Tbk (BABP), Bank Capital Indonesia Tbk (BACA), Bank Mutiara Tbk (BCIC), dan Bank Pundi Indonesia Tbk (BEKS) tidak memenuhi persyaratan penelitian karena perbandingan ekuitas yang terlalu kecil dibandingkan kewajiban yang dimiliki, sehingga menghasilkan nilai negatif pada ekuitasnya. Keempat bank tersebut menyebabkan tidak normalnya data, sehingga harus dieliminasi sebagai syarat pengolahan analisis regresi. Oleh sebab itu diperoleh jumlah sampel yang memenuhi kriteria sebanyak 22 perusahaan.

Proses pengolahan data dalam penelitian ini bersifat saling bebas antara variabel kepemilikan manajerial terhadap kebijakan pendanaan dan kepemilikan manajerial terhadap kebijakan dividen. Ketiga variabel yang ada dalam penelitian ini tidak saling terikat karena karakteristik perbankan yang ketat dengan peraturan menyebabkan perbedaan dengan sektor industri lainnya yang telah dijadikan objek penelitian sebelumnya.

Tahap awal sebelum masuk dalam pengolahan analisis regresi, dilakukan uji asumsi klasik. Statistik deskriptif memberikan informasi variabel-variabel dalam penelitian yang dilihat dari nilai rata-rata (mean), standar deviasi, nilai maksimum, dan nilai minimun. Hasil analisis statistik deskriptif tiap-tiap variabel dalam penelitian disajikan pada Tabel 2.

Tabel 2. Analisis statistik deskriptif

\begin{tabular}{lccccc}
\hline & $\boldsymbol{n}$ & Minimum & Maximum & Mean & Std. Deviation \\
\hline DER & 22 & 452.44809 & 1368.17951 & 884.8275298 & 227.70224348 \\
MOWN & 22 & .00002 & 95.86523 & 35.6262934 & 38.23222657 \\
DPR & 22 & .00000 & 65.85136 & 17.2920531 & 16.89357214 \\
Valid N (listwise) & 22 & & & & \\
\hline
\end{tabular}

Berdasarkan Tabel 2, jumlah sampel yang digunakan adalah 22 perusahaan. DER sebagai variabel dependen memiliki nilai minimal sebesar 452.44809 dengan nilai maksimal 1368.17951, rata-rata 884.8275298, dan standar deviasi 227.70224348. MOWN sebagai variabel independen memiliki nilai minimal 0.00002 , nilai maksimal 95.86523, rata-rata 35.6262934, dan standar deviasi 38.23222657. DPR sebagai variabel dependen memiliki nilai minimal sebesar 0.00, nilai maksimal 65.85136, ratarata 17.2920531 , dan standar deviasi 16.89357214 .

Selanjutnya, uji normalitas data menguji kenormalan variabel. Uji normalitas ini menggunakan metode Kolmogorov-Smirnov (KS). Jika nilai KShitung < KStabel atau 
P-value $>5 \%$ maka data regresi mengikuti sebaran normal (Baroroh 2013). Berikut hasil pengujian variabel-variabel penelitian tersebut.

Tabel 3. Uji normalitas data

\begin{tabular}{lcccccc}
\hline & \multicolumn{3}{c}{ Kolmogorov-Smirnov $^{a}$} & \multicolumn{3}{c}{ Shapiro-Wilk } \\
\cline { 2 - 7 } & Statistic & Df & Sig. & Statistic & Df & Sig. \\
\hline DER & .154 & 22 & .190 & .950 & 22 & .322 \\
DPR & .153 & 22 & .197 & .878 & 22 & .011 \\
\hline
\end{tabular}

Berdasarkan Tabel 3, variabel dependen mengikuti distribusi normal. Metode Kolmogorov-Smirnov menunjukkan hasil P-value atau Sig $>0.05$. Pengujian DER menunjukkan sig $(0.190)>0.05$, serta DPR menunjukkan sig $(0.197)>0.05$ yang berarti bahwa data variabel dependen mengikuti sebaran normal dan layak untuk dianalisis lebih lanjut. Selain dilihat dari nilai sig. juga dinilai dari perbandingan hasil KShitung (statistik) dengan KStabel. Tabel 3 menunjukkan nilai KShitung DER (0.154) < KStabel (22:0.05), dan KShitung DPR (0.153) < KStabel (22:0.05), nilai KStabel adalah 0.28087. Hasil ini menunjukkan data variabel yang akan diuji megikuti sebaran normal.

Data yang baik sebagai persyaratan untuk diolah dengan analisis regresi adalah menunjukkan kehomogenan data yang digunakan. Pengujian ditunjukkan oleh diagram pencar yang membentuk pola seragam (Agung 2005). Apabila ada pola heterogenitas data maka data tidak lolos pengujian ke tahap regresi. Berikut hasil pengujian yang dituangkan dalam diagram pencar dari tiap-tiap variabel.

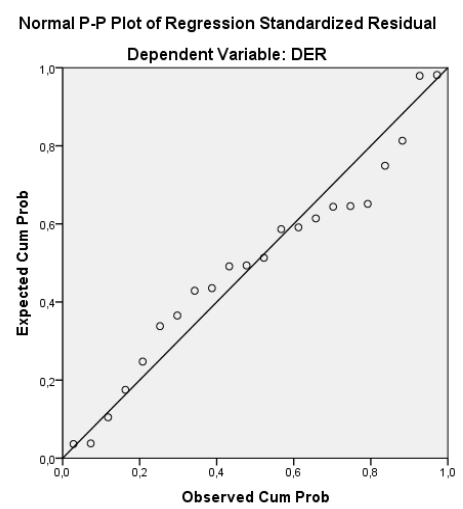

Gambar 3. P-P Plot DER dan MOWN

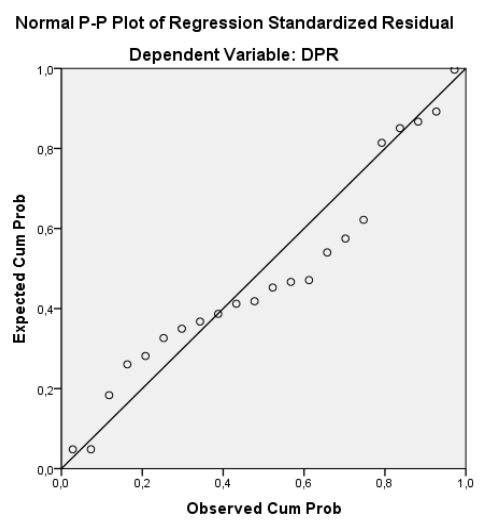

Gambar 4. P-P Plot DPR dan MOWN 
Gambar 3 dan Gambar 4 menunjukkan persebaran titik data sampel pada variabel yang ada adalah seragam dan mengikuti pola yang sama. Hal ini menunjukkan bahwa data variabel penelitian ini homogen dan layak diuji ke tahap regresi. Persyaratan uji asumsi klasik selanjutnya adalah uji autokorelasi, menggunakan uji Durbin-Watson. Data penelitian yang baik adalah ketika tidak terjadi autokorelasi, dilihat dari variabel bebasnya. Variabel bebas pada penelitian ini hanya satu maka untuk melihat nilai dU pada tabel dengan $\mathrm{k}=1$ ( $\mathrm{k}$ adalah simbol banyaknya variabel bebas) dan jumlah objek yang dianalisis $n=22$ perusahaan perbankan. Oleh karena itu, didapatkan nilai dU=1.4289 pada tabel Durbin-Watson dengan $\alpha=0.05$. Berikut tabel hasil uji autokorelasi pada variabel independen serta penjelasan hasil analisis regresi antar variabel dalam penelitian ini.

Tabel 4. Uji autokorelasi MOWN terhadap DER

\begin{tabular}{cccccc}
\hline Model & $\boldsymbol{R}$ & $\boldsymbol{R}$-square & Adjusted $R$-square & Std. Error of the Estimate & Durbin-Watson \\
\hline 1 & $.098^{\mathrm{a}}$ & .010 & -.040 & 232.20775825 & 2.385 \\
\hline
\end{tabular}

a. Predictors: (Constant), MOWN

b. Dependent Variable: DER

Tabel 5. Uji autokorelasi MOWN terhadap DPR

\begin{tabular}{cccccc}
\hline Model & $\boldsymbol{R}$ & $\boldsymbol{R}$-square & Adjusted $R$-square & Std. Error of the Estimate & Durbin-Watson \\
\hline 1 & $.492^{\mathrm{a}}$ & .242 & .204 & 15.06841213 & 1.618 \\
\hline
\end{tabular}

a. Predictors: (Constant), MOWN

b. Dependent Variable: DPR

Uji autokorelasi pada Tabel 4, variabel independen MOWN yang terkait dengan variabel dependen DER ditunjukkan oleh hasil pada kolom Durbin-Watson senilai (d) 2.385. Hasil uji Durbin-Watson dibandingkan dengan nilai $\mathrm{dU}=1.4289$, terletak di antara dU dan 4-dU yang diperjelas dengan nilai $1.4289<2.385<2.5711$. Apabila nilai uji dU $<\mathrm{d}<4$-dU maka data tidak terjadi autokorelasi, sehingga variabel independen MOWN terhadap variabel dependen DER dapat dilakukan uji analisis regresi (Santoso 2010). Pada Tabel 5, uji autokorelasi variabel independen MOWN yang terkait dengan variabel dependen DER hasil Durbin-Watson senilai (d) 1.618. Nilai $d$ ini menunjukkan tidak terjadi autokorelasi, sehingga variabel independen dapat dilakukan analisis regresi dengan variabel dependennya.

Setelah lolos uji asumsi klasik, Tabel 4 dan Tabel 5 juga menunjukkan hasil analisis regresi yang ditunjukkan oleh nilai $R$-square. Tabel 4 menunjukkan hubungan antara variabel DER dengan MOWN dengan $R$-square senilai 0.01 atau $1 \%$. Debt Equity Ratio dapat dijelaskan oleh variabel independennya yaitu Managerial Ownership hanya sebesar $1 \%$ dan sisanya $99 \%$ dapat dijelaskan oleh faktor lainnya. Pada Tabel 5 , hubungan antara variabel DPR dengan MOWN menunjukkan $R$-square senilai 0.242 atau 24.2\%. Dividend Payout Ratio dapat dijelaskan oleh variabel independennya Managerial Ownership sebesar $24.2 \%$ dan sisanya $75.8 \%$ dijelaskan oleh faktor lainnya.

Tahapan dalam pengujian analisis regresi juga menjelaskan signifikansi hubungan antar variabel independen dan dependennya. Uji parameter ini dilihat dari Tabel ANOVA melalui nilai uji F yang ada di dalamnya (Trihendradi 2013). 
Tabel 6. Uji ANOVA DER dan MOWN

\begin{tabular}{llccccc}
\hline & Model & Sum of Squares & Df & Mean Square & $\boldsymbol{F}$ & Sig. \\
\hline 1 & Regression & 10405.686 & 1 & 10405.686 & .193 & $.665^{\mathrm{b}}$ \\
& Residual & 1078408.860 & 20 & 53920.443 & & \\
& Total & 1088814.545 & 21 & & & \\
\hline
\end{tabular}

a. Dependent Variable: DER

b. Predictors: (Constant), MOWN

Tabel 7. Uji ANOVA DPR dan MOWN

\begin{tabular}{llccccc}
\hline & Model & Sum of Squares & Df & Mean Square & F & Sig. \\
\hline 1 & Regression & 1452.107 & 1 & 1452.107 & 6.395 & $.020^{\mathrm{b}}$ \\
& Residual & 4541.141 & 20 & 227.057 & & \\
& Total & 5993.248 & 21 & & & \\
\hline
\end{tabular}

a. Dependent Variable: DPR

b. Predictors: (Constant), MOWN

Tabel ANOVA memaparkan linieritas antar variabel. Tabel 6 menunjukkan hubungan linieritas antara DER dan MOWN tidak signifikan karena nilai $F$ hitung $(0.193)$ < F-tabel $(1 ; 20 ; 0.05)$, nilai Ftabel adalah 4.35. Selain itu dilihat dari nilai Sig $(0.665)>\alpha(0.05)$ yang menunjukkan hubungan antar variabel DER dan MOWN tidak signifikan. Sedangkan Tabel 7 menunjukkan hubungan linieritas antara DPR dan MOWN signifikan karena nilai Fhitung (6.395) > Ftabel $(1 ; 20 ; 0.05)$, serta dilihat dari nilai Sig $(0.02)<\alpha(0.05)$.

Persamaan dalam analisis regresi yang menggambarkan hubungan antar variabelnya ditunjukkan dalam Tabel 9, juga menjelaskan hubungan positif atau negatif antar variabel serta signifikansi hubungan antar variabelnya. Tabel koefisien pada kolom t menunjukkan hubungan tersebut. Apabila nilai t hitung mutlak $>$ t-Tabel maka hubungan antar variabel signifikan, serta nilai Sig $<0.05$. Kemudian nilai t sebenarnya sebelum dibandingkan dengan t-Tabel (1.96), tanda positif atau negatif menunjukkan hubungan variabelnya. Tabel 8 menunjukkan koefisien variabel DER dan MOWN memiliki hubungan positif dan tidak signifikan, sedangkan Tabel 9 menunjukkan koefisiean variabel DPR dan MOWN memiliki hubungan negatif dan signifikan.

Tabel 8. Koefisien variabel DER dan MOWN

\begin{tabular}{|c|c|c|c|c|c|c|c|}
\hline \multirow{2}{*}{ Model } & \multicolumn{2}{|c|}{$\begin{array}{c}\text { Unstandardized } \\
\text { Coefficients }\end{array}$} & \multirow{2}{*}{$\begin{array}{c}\begin{array}{c}\text { Standardized } \\
\text { Coefficients }\end{array} \\
\text { Beta }\end{array}$} & \multirow{2}{*}{$T$} & \multirow{2}{*}{ Sig. } & \multicolumn{2}{|c|}{$\begin{array}{c}95.0 \% \text { Confidence } \\
\text { Interval for B }\end{array}$} \\
\hline & B & Std. Error & & & & $\begin{array}{l}\text { Lower } \\
\text { Bound }\end{array}$ & $\begin{array}{l}\text { Upper } \\
\text { Bound }\end{array}$ \\
\hline 1 (Constant) & 864.085 & 68.414 & & 12.630 & .000 & 721.376 & 1006.794 \\
\hline MOWN & .582 & 1.325 & .098 & .439 & .665 & -2.182 & 3.347 \\
\hline
\end{tabular}

Tabel 9. Koefisien variabel DPR dan MOWN

\begin{tabular}{ccccccccc}
\hline \multirow{2}{*}{ Model } & \multicolumn{2}{c}{ Unstandardized Coefficients } & $\begin{array}{c}\text { Standardized } \\
\text { Coefficients }\end{array}$ & \multirow{2}{*}{ T } & Sig. & \multicolumn{2}{c}{$\begin{array}{c}\text { 95.0 \% Confidence } \\
\text { Interval for } \boldsymbol{B}\end{array}$} \\
\cline { 2 - 4 } & $\boldsymbol{B}$ & Std. Error & Beta & & & Lower Bound & $\begin{array}{c}\text { Upper } \\
\text { Bound }\end{array}$ \\
\hline (Constant) & 25.041 & 4.440 & & & 5.640 & .000 & 15.780 & 34.301 \\
MOWN & -.218 & .086 & -.492 & -2.529 & .020 & -.397 & -.038 \\
\hline a. Dependent Variable: DPR & & & & & & \\
\hline
\end{tabular}


III.2. Pengaruh Kepemilikan Manajerial terhadap Kebijakan Pendanaan

Berdasarkan hasil uji statistik nilai signifikansi pada Tabel ANOVA dan Tabel koefisien Sig $(0.665)>0.05$, serta nilai t hitung 4.39, menunjukkan bahwa kepemilikan manajerial berpengaruh positif tetapi tidak signifikan terhadap kebijakan pendanaan. Hasil dari pengolahan regresi, nilai $R$-square 0.01 artinya hanya $1 \%$ kepemilikan manajerial berperan dalam kebijakan pendanaan, $99 \%$ dipengaruhi faktor lainnya.

Ditinjau dari hipotesis pertama $\left(\mathrm{H}_{1}\right)$, bahwa semakin tinggi kepemilikan manajerial maka semakin tinggi kebijakan pendanaan diterima. Karena dana pihak ketiga merupakan kewajiban perusahaan, besarnya total kewajiban (liabilities) dibandingkan ekuitas yang dimiliki menyebabkan kebutuhan dana tidak bisa mengandalkan saham manajerial. Hal inilah yang menyebabkan hubungan antar variabel independen MOWN dan variabel dependen DER tidak signifikan. Hubungan tidak signifikan ini mencerminkan bahwa manajer perusahaan bukanlah faktor utama dalam pengambilan keputusan pendanaan dari utang, karena saham manajerial yang dimiliki tiap-tiap bank berbeda dan tidak ada aturan mengikat tentang kepemilikan saham manajerial.

Pada umumnya, semakin meningkat DER menimbulkan kekhawatiran karena berarti meningkatnya utang perusahaan sehingga meningkatkan potensi perusahaan tidak mampu membayar utang kepada pihak ketiga. Namun, hal berlainan terjadi pada sub-sektor perbankan karena semakin tinggi utang (liabilities) yang dalam perbankan meliputi dana pihak ketiga (DPK), akan semakin baik dengan syarat diikuti oleh penyaluran kredit kepada masyarakat secara proporsional.

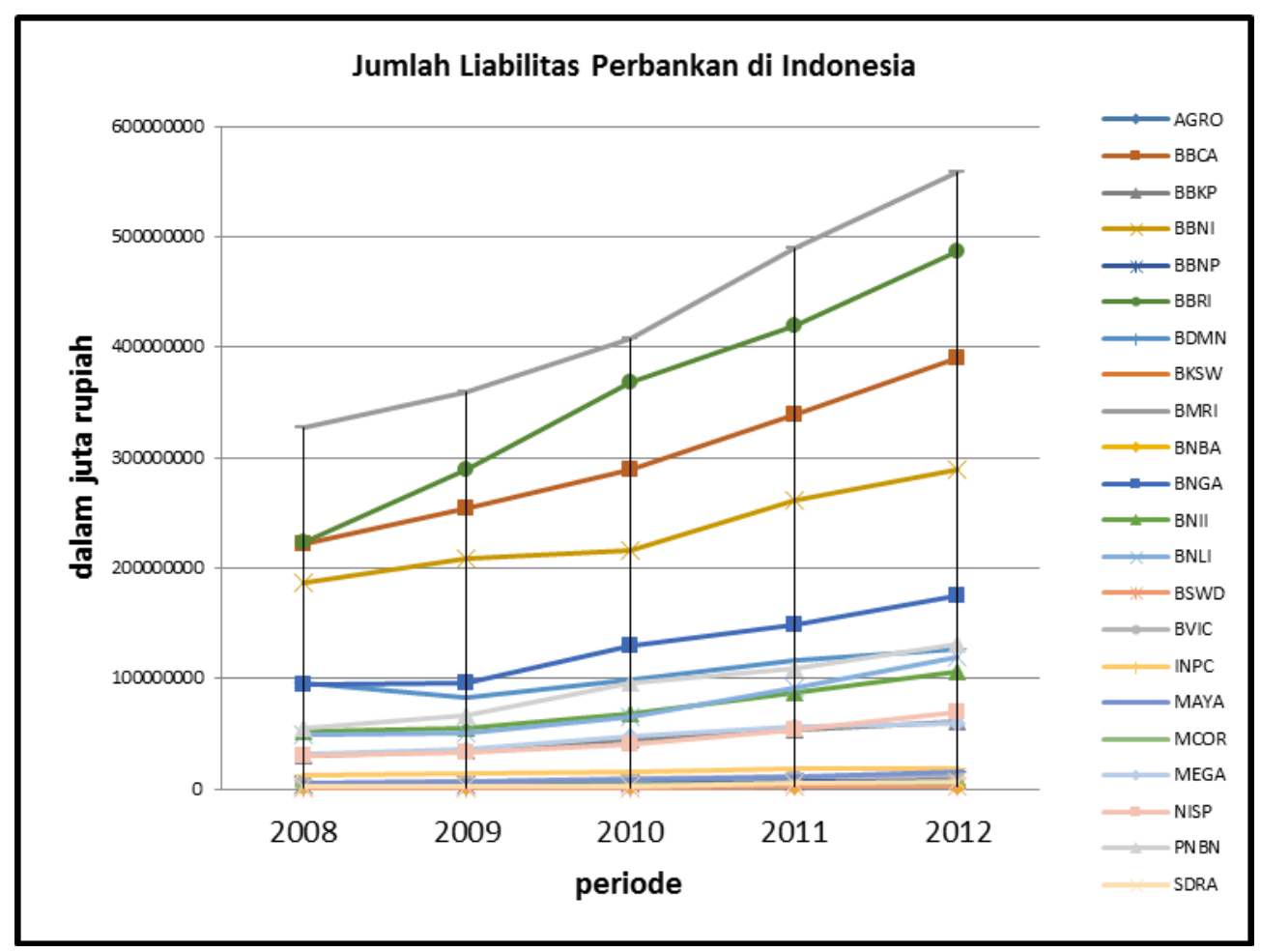

Gambar 5. Grafik pertumbuhan liabilitas perbankan (BEI 2013) 
Hal ini diperkuat oleh karakteristik perbankan yang berbeda dengan sektor industri lainnya berkaitan kewajiban perusahaan. Pada perbankan, jumlah kewajiban juga mencakup DPK (tabungan, deposito berjangka, giro) yang dapat mancapai $80 \%$ dari total kewajiban, sementara sisanya merupakan utang dan pinjaman lainnya. Besarnya angka DER pada sub sektor perbankan dianggap wajar dengan syarat penyaluran kreditnya proporsional dengan penambahan dana pihak ketiga (DPK).

Penambahan dana pihak ketiga ini ada hubungannya dengan besarnya kredit yang disalurkan bank kepada masyarakat. Semakin tinggi dana pihak ketiga yang dihimpun, bank dituntut menyalurkan kredit lebih besar juga. Oleh sebab itu, MOWN akan lebih mendorong kebijakan penambahan DPK sebagai sumber utama kredit yang disalurkan. Hal ini diperjelas dengan ketetapan nilai Loan to Deposit Ratio (LDR) dalam Surat Edaran Bank Indonesia Nomor 15/41/dkmp (2014), serta ketentuan dalam Peraturan Bank Indonesia Pasal 9 dan Pasal 10 PBI NO. 15/7/PBI/2013 (2013) tentang pemenuhan Giro Wajib Minimum Sekunder dan Giro Wajib Minimum (GWM) berdasarkan LDR, yaitu perbankan harus mencapai LDR target $78 \%-92 \%$ sejak Desember 2013. Apabila bank tidak mampu mencapai LDR target, maka bank akan dikenakan penalti tambahan GWM yang harus diserahkan ke Bank Indonesia (BI). Bank akan rugi jika tidak mencapai target, karena penyerahan peningkatan penalti GWM tersebut akan menyulitkan ekspansi perusahaan.

Berkaitan teori signalling, menurut Mardiyati et al. (2012), semakin tinggi utang akan memberi sinyal positif kepada para investor mengenai prospek perusahaan yang lebih baik di masa depan. Manajer menggunakan utang lebih banyak untuk menyampaikan sinyal kepada investor dan nasabah bank. Sinyal tersebut mengindikasikan bahwa bank memiliki prospek baik yang diikuti dengan syarat penyaluran kredit kepada masyarakat secara proporsional.

\section{III.3. Pengaruh Kepemilikan Manajerial terhadap Kebijakan Dividen}

Berdasarkan hasil uji statistik nilai signifikansi pada Tabel ANOVA dan Tabel koefisien Sig $(0.02)<0.05$, serta nilai t hitung -2.529 menunjukkan bahwa kepemilikan manajerial berpengaruh negatif dan signifikan terhadap kebijakan dividen. Hasil pengolahan regresi, nilai $R$-square 0.242 yang berarti $24.2 \%$ kepemilikan manajerial berperan dalam kebijakan dividen, $75.8 \%$ dipengaruhi faktor lainnya. Ditinjau dari hipotesis kedua $(\mathrm{H} 2)$, semakin tinggi kepemilikan manajerial maka semakin rendah DPR dapat diterima. Ini menunjukkan bahwa pemegang saham manajerial lebih memilih mendapatkan kompensasi (gaji, tunjangan, dan bonus) dibandingkan dengan dividen yang dibagikan perusahaan. Demikian juga perbankan yang memilih tidak membagikan dividennya dan menggunakannya untuk ekspansi perusahaan serta cadangan umum dan wajib perusahaan.

Besarnya persentase remunerasi untuk direksi, komisaris, serta manajer perbankan di Indonesia sangat besar dibandingkan dengan sektor lainnya. Tingginya remunerasi direksi dan komisaris perbankan diterapkan dengan prinsip equal pay for equal job. Semakin tinggi level dan kedudukannya semakin besar pula tanggung jawab dan risiko yang diemban, yang diikuti dengan paket remunerasi yang besar juga. Hal ini didukung dengan adanya peran dan tugas Komite Nominasi dan Remunerasi di Indonesia menurut Good Corporate Governance Komite Nasional Kebijakan 
Governance (GCG KNKG), yang membantu Dewan Komisaris (Dekom) dalam penetapan kriteria pemilihan anggota Dekom dan Direksi beserta sistem remunerasinya, membantu Dekom mempersiapkan calon anggota Dekom dan Direksi serta mengusulkan besaran remunerasinya (Cintya 2014).

Besaran remunerasi komisaris dan direksi pada tahun 2008 sebesar Rp16 071.41 juta, tahun 2009 Rp16 529.30 juta, tahun 2010 Rp19 778.73 juta, dan tahun 2011 Rp23 450.36 juta. Peningkatan laba secara agregat pada bank umum di Indonesia ratarata Rp237 650.39 juta tahun 2008, Rp360 411.21 juta tahun 2009, Rp488 841.22 juta tahun 2010, dan Rp626 664.5 juta pada 2011. Hal ini menunjukkan bahwa kinerja perusahaan terus membaik untuk mencapai laba maksimal serta pemberian remunerasi tinggi dijadikan reward untuk direksi dan komisaris bank di Indonesia (Infobank 2010; Infobank 2011; Mohammad 2012).

Hal inilah yang menyebabkan masalah keagenan antara pemegang saham dan manajemen, saat dividen tidak dibagikan dan cenderung dijadikan sebagai laba ditahan. Laba ditahan tersebut digunakan untuk ekspansi usaha lebih besar, baik untuk perusahaan induk ataupun perusahaan anak. Perbankan melakukan ekspansi untuk meningkatkan laba, dan dengan demikian akan dapat meningkatkan remunerasi untuk manajemen. Hubungan yang terjadi antara kepemilikan manajerial dengan kebijakan pembagian dividen merupakan pandangan kebijakan dividen tidak relevan. Pandangan ini dijelaskan oleh Miller dan Mondligiani dalam Mardiyati et al. (2012) bahwa nilai suatu perusahaan tidak ditentukan oleh besar kecilnya DPR, tetapi ditentukan oleh laba bersih sebelum pajak (EBIT) dan risiko perusahaan. Dividen tidak relevan diperhitungkan karena tidak mempengaruhi peningkatan kesejahteraan pemegang saham (pihak manajerial) (Brigham dan Houston 2003). Oleh sebab itu, pihak manajerial lebih tertarik pada besarnya paket remunerasi dibandingkan dengan besarnya dividen yang dibagikan.

\section{Kesimpulan}

Kepemilikan manajerial tidak berpengaruh signifikan terhadap kebijakan pendanaan. Sedangkan kepemilikan manajerial berpengaruh negatif dan signifikan terhadap kebijakan dividen. Nilai $D E R$ yang tinggi pada perbankan sebagai hal yang wajar, karena karakteristik perbankan berbeda dengan sektor industri lainnya. Kepemilikan manajerial tidak signifikan terhadap DER karena pendanaan yang digunakan bank tidak hanya berasal dari saham manajerial melainkan juga dari dana pihak ketiga sebagai kewajiban perusahaan. Hal ini disebabkan oleh kecilnya proporsi kepemilikan manajerial dibandingkan dengan sumber dana lainnya pada sektor perbankan. Sedangkan nilai kepemilikan manajerial terhadap DPR berpengaruh negatif karena pembagian remunerasi yang tinggi untuk direksi dan komisaris bank menyebabkan tidak terlalu pentingnya pembagian dividen untuk pihak manajerial, dan manajemen lebih memilih pada paket remunerasi yang didapatkan. 


\section{Daftar Pustaka}

Agung IGN. 2005. Manajemen Penulisan Skripsi, Tesis, dan Disertasi. Jakarta (ID): Raja Grafindo Persada. Ed ke-1.

[BEI] Bursa Efek Indonesia. 2013. Annual Report Perbankan 2008-2012 [internet]. [diunduh pada Desember 2013]. Tersedia pada : http://www.idx.co.id/annualreport/.

Baraoroh A. 2013. Analisis Multivariat dan Time Series dengan SPSS 21. Jakarta (ID): PT. Elex Media Komputindo.

Brigham EF, Houston JF. 2003. Fundamentals of Financial Management : Dasar-Dasar Manajemen Keuangan. Jakarta (ID) : Salemba Empat. Ed ke-10.

Cintya PYA. 2014. Komite Nominasi dan Remunerasi di Perusahaan Indonesia Untuk Pelaksanaan Enterprise Risk Management (ERM) yang lebih baik [internet]. [diunduh pada 2014 Maret 11]. Tersedia pada : http://www.crmsindonesia.org/node/653.

Infobank. 2011. Besar Kecil Gaji Bankir. XXXIII (391): 8-14.

Infobank. 2010. Naik-Naik ke Puncak Gaji. XXXII (379): 12-20.

Kahar SHA. 2008. Kepemilikan manajerial terhadap kebijakan pendanaan dan kebijakan dividen. Jurnal Keuangan dan Perbankan. 12(3): 399-410.

Larasati E. 2011. Pengaruh kepemilikan manajerial, kepemilikan institusional, dan kebijakan dividen terhadap kebijakan utang perusahaan. Jurnal Ekonomi Bisnis. 16(2): 103-107.

Malik F, S Gul MT, Khan SU, Rehman MK. 2013. "Factors influencing corporate dividend payout dicisions of financial and non-financial firms." Research Journal of Finance and Accounting. 4 (1): 35-46.

Mardiyati U, Ahmad GN, Putri R. 2012. Pengaruh kebijakan dividen, kebijakan utang, dan profitabilitas terhadap nilai perusahaan manufaktur yang terdaftar di Bursa Efek Indonesia (BEI) Periode 2005-2010. Jurnal Riset Manajemen Sains Indonesia. 3(1): 1-17.

Mohammad K. 2012. Remunerasi Bankir Kian Bikin Ngiler. Infobank. XXXIV (403): 57-63

Peraturan Bank Indonesia 15/7/PBI/2013. 2013. Peraturan Perbankan [internet]. [diunduh pada 2014 Maret 11]. Tersedia pada: http://www.ojk.go.id/peraturanbank-indonesia-nomor-15-07-pbi-2013.

Peraturan Pemerintah Nomer 29 tahun 1999. 1999. Peraturan Perbankan [internet]. [diunduh pada 2014 Maret 11]. Tersedia pada: http://www.ojk.go.id/Files/peraturan/pemerintah/perbankan/1999-029-99.pdf

Putri IF, Nasir M. 2006. Analisis Persamaan Simultan Kepemilikan Manajerial, Kepemilikan Institusional, Risiko, Kebijakan Utang, dan Kebijakan Dividen dalam Perspektif Teori Keagenan. Simposium Nasional Akuntansi 9 Padang [Internet]. [Padang, 23-26 Agustus 2006]. Padang (ID): Universitas Sumatera Utara. hlm 125; [diunduh pada 2013 Oktober 1]. Tersedia pada: http://blog.umy.ac.id/ervin/files/2012/06/K-AKPM-18.pdf

Rachmad AN, Muid D. 2013. Pengaruh struktur kepemilikan, leverage, dan return on assets (ROA) terhadap kebijkan dividen (studi empiris pada perusahaan nonkeuangan yang terdaftar di Bursa Efek Indonesia). Diponegoro Journal of Accounting. 2(3): 1-11. 
Santoso S. 2010. Mastering SPSS 18. Ed ke-1. Jakarta (ID): PT. Elex Media Komputindo. Sharma DK, R Wadhwa. 2013. Ownership structure and dividend policy-A study of Bombay Stock Exchange-500. Global Journal of Management and Business Studies. 3 (4): 429-434.

Soesetio Y. 2008. Kepemilikan manajerial dan institusional, kebijakan dividen, ukuran perusahaan, struktur aktiva, dan profitabilitas terhadap kebijakan utang. Jurnal Keuangan dan Perbankan. 12(3): 399-410.

Surat Edaran Bank Indonesia Nomer 15/41dkmp. 2014. Peraturan Perbankan [internet]. [diunduh pada 2014 Maret 11]. Tersedia pada: http://www.ojk.go.id/surat-edaran-bank-indonesia-nomor-15-41-dkmp.

Trihendradi C. 2013. Step by Step IBM SPSS 21: Analisis Data Statistik. Ed ke-1. Yogyakarta (ID) : Andi Offset. 